\title{
Front Matter: Volume 9695
}

, "Front Matter: Volume 9695," Proc. SPIE 9695, Mechanisms of Photobiomodulation Therapy XI, 969501 (22 June 2016); doi:

$10.1117 / 12.2231315$

SPIE. Event: SPIE BiOS, 2016, San Francisco, California, United States 


\title{
Mechanisms of Photobiomodulation Therapy XI
}

\author{
Michael R. Hamblin \\ James D. Carroll \\ Praveen Arany \\ Editors
}

13-14 February 2016

San Francisco, California, United States

Sponsored and Published by

SPIE 
The papers in this volume were part of the technical conference cited on the cover and title page. Papers were selected and subject to review by the editors and conference program committee. Some conference presentations may not be available for publication. Additional papers and presentation recordings may be available online in the SPIE Digital Library at SPIEDigitallibrary.org.

The papers reflect the work and thoughts of the authors and are published herein as submitted. The publisher is not responsible for the validity of the information or for any outcomes resulting from reliance thereon.

Please use the following format to cite material from this book:

Author(s), "Title of Paper," in Mechanisms of Photobiomodulation Therapy XI, edited by Michael R. Hamblin, James D. Carroll, Praveen Arany, Proceedings of SPIE Vol. 9695 (SPIE, Bellingham, WA, 2016) Six-digit Article CID Number.

ISSN: 1605-7422

ISSN: 2410-9045 (electronic)

ISBN: 9781628419290

Published by

SPIE

P.O. Box 10, Bellingham, Washington 98227-0010 USA

Telephone +1 3606763290 (Pacific Time) · Fax +1 3606471445

SPIE.org

Copyright (C) 2016, Society of Photo-Optical Instrumentation Engineers.

Copying of material in this book for internal or personal use, or for the internal or personal use of specific clients, beyond the fair use provisions granted by the U.S. Copyright Law is authorized by SPIE subject to payment of copying fees. The Transactional Reporting Service base fee for this volume is $\$ 18.00$ per article (or portion thereof), which should be paid directly to the Copyright Clearance Center (CCC), 222 Rosewood Drive, Danvers, MA 01923. Payment may also be made electronically through CCC Online at copyright.com. Other copying for republication, resale, advertising or promotion, or any form of systematic or multiple reproduction of any material in this book is prohibited except with permission in writing from the publisher. The CCC fee code is $1605-7422 / 16 / \$ 18.00$.

Printed in the United States of America.

Publication of record for individual papers is online in the SPIE Digital Library.

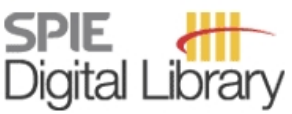

SPIEDigitallibrary.org

Paper Numbering: Proceedings of SPIE follow an e-First publication model, with papers published first online and then in print. Papers are published as they are submitted and meet publication criteria. A unique citation identifier (CID) number is assigned to each article at the time of the first publication. Utilization of CIDs allows articles to be fully citable as soon as they are published online, and connects the same identifier to all online, print,

and electronic versions of the publication. SPIE uses a six-digit CID article numbering system in which:

- The first four digits correspond to the SPIE volume number.

- The last two digits indicate publication order within the volume using a Base 36 numbering

system employing both numerals and letters. These two-number sets start with 00, 01, 02, 03, 04, $05,06,07,08,09,0 A, 0 B \ldots 0 Z$, followed by 10-1Z, 20-2Z, etc.

The CID Number appears on each page of the manuscript. The complete citation is used on the first page, and an abbreviated version on subsequent pages. 


\title{
Contents
}

\author{
$\checkmark$ Authors \\ vii Conference Committee
}

\section{SESSION 1 PRESENT STATUS AND FUTURE DIRECTION WITH PBM THERAPY}

969503 Blue light inhibits proliferation of melanoma cells [9695-2]

969505 Effect of interstitial low level laser stimulation in skin density [9695-4]

969506 Biochemical changes on the repair of surgical bone defects grafted with biphasic synthetic micro-granular HA + $\beta$-tricalcium phosphate induced by laser and LED phototherapies assessed by Raman spectroscopy [9695-5]

\section{SESSION 2 CLINICAL TRANSLATIONAL RESEARCH WITH PBM THERAPY}

969508 Photobiomodulation of distinct lineages of human dermal fibroblasts: a rational approach towards the selection of effective light parameters for skin rejuvenation and wound healing [9695-7]

969509 Effects of low-level laser exposure on calcium channels and intracellular release in cultured astrocytes (Invited Paper) [9695-8]

9695 OA In vitro measurements of oxygen consumption rates in hTERT-RPE cells exposed to low levels of red light [9695-9]

\section{SESSION 3 CLINICAL APPLICATIONS OF PBM THERAPY}

9695 OD Effect of interstitial low level laser therapy on tibial defect [9695-12]

\section{SESSION 4 PBM SYNERGISTIC THERAPIES}

$9695 \mathrm{OH} \quad$ Low-power laser irradiation did not stimulate breast cancer cells following ionizing radiation [9695-18]

$96950 \mathrm{~J}$ Biochemical responses of isolated lung CSCs after application of low intensity laser irradiation [9695-28] 
$9695 \mathrm{OL}$ Assessment of the influence of Laser phototherapy on the bone repair process of complete fractures in tibiae of rabbits stabilized with semi-rigid internal fixation treated with or without MTA graft: a histological study [9695-17]

9695 ON A new visual analog scale to measure distinctive well-being effects of LED photobiomodulation [9695-20]

969500 Photodynamic antimicrobial chemotherapy (PACT) against oral microorganisms with the use of blue LED associated to curcumin [9695-21]

9695 OP Effect of Low-Level Laser therapy on the fungal proliferation of Candida albicans [9695-22]

9695 OR PDT in non-surgical treatment of periodontitis in kidney transplanted patients: a split-mouth, randomized clinical trial [9695-24]

$96950 S \quad$ PDT in periodontal disease of HAART resistance patients [9695-25]

9695 OT Assessment of the effects of laser photobiomodulation on peri-implant bone repair through energy dispersive x-ray fluorescence: A study of dogs [9695-26] 


\section{Authors}

Numbers in the index correspond to the last two digits of the six-digit citation identifier (CID) article numbering system used in Proceedings of SPIE. The first four digits reflect the volume number. Base 36 numbering is employed for the last two digits and indicates the order of articles within the volume. Numbers start with 00, 01, 02, 03, 04, 05, 06, 07, 08, 09, OA, OB...0Z, followed by 10-12, 20-2Z, etc.

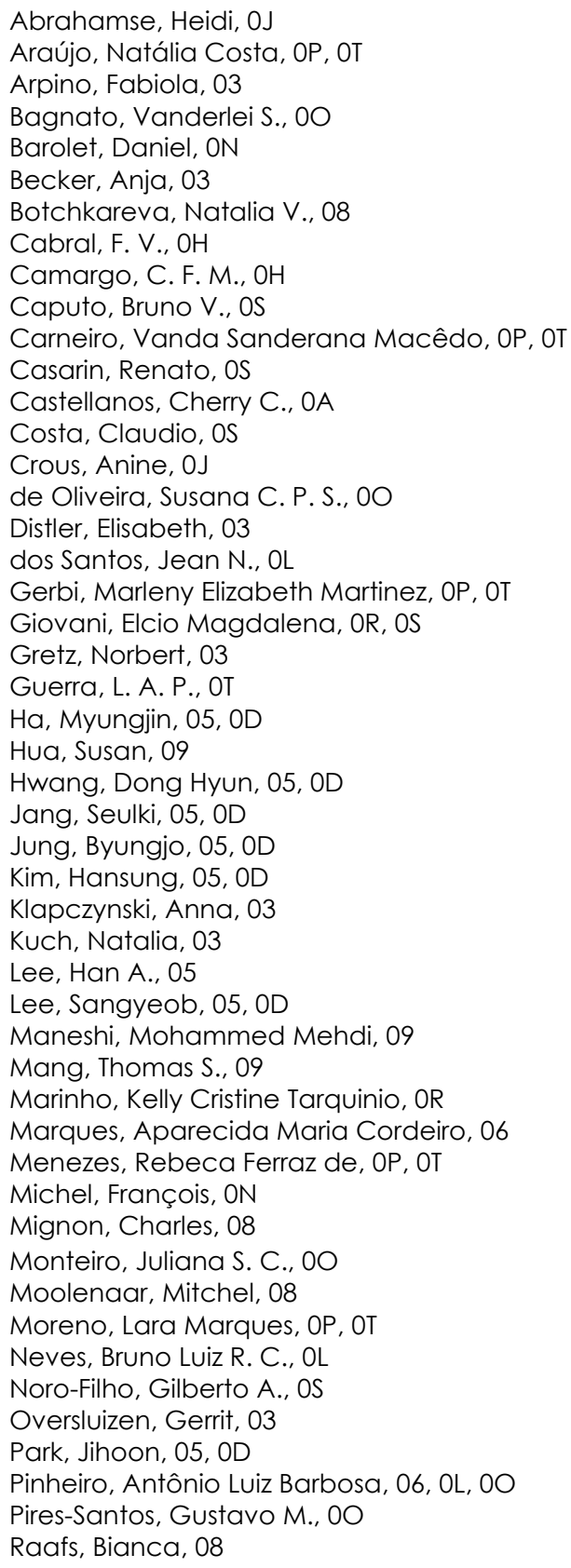

Radfar, Edalat, 05, OD

Ribeiro, M. S., $\mathrm{OH}$

Sachs, Frederick, 09

Salgado, Daniela, OS

Sampaio, Fernando José Pires, 00

Santos, Camila C., OS

Santos, Nicole R. S., OL

Santos-Neto, Alexandrino Pereira dos, OP, OT

Shucard, David Wm., 09

Silva, Aline C. P., OL

Silva, Anna Paula L. T., OL

Silva, C. R., $\mathrm{OH}$

Silveira, Landulfo, Jr., 06

Simon-Keller, Katja, 03

Soares, Luiz Guilherme Pinheiro, 06, 0L

Sticht, Carsten, 03

Tobin, Desmond J., 08

Uzunbajakava, Natallia E., 08

van Abeelen, Frank A., 03

Wigle, Jeffrey C., OA

Yu, Sungkon, 05, OD 
Proc. of SPIE Vol. $9695969501-6$

Downloaded From: https://www.spiedigitallibrary.org/conference-proceedings-of-spie on 26 Apr 2023 Terms of Use: https://www.spiedigitallibrary.org/terms-of-use 


\title{
Conference Committee
}

\author{
Symposium Chairs
}

James G. Fujimoto, Massachusetts Institute of Technology

(United States)

R. Rox Anderson, Wellman Center for Photomedicine, Massachusetts General Hospital (United States) and Harvard School of Medicine (United States)

Program Track Chair

Brian Jet-Fei Wong, Beckman Laser Institute and Medical Clinic (United States)

Conference Chairs

Michael R. Hamblin, Wellman Center for Photomedicine (United States)

James D. Carroll, THOR Photomedicine Ltd. (United Kingdom)

Praveen Arany, University at Buffalo (United States)

Conference Program Committee

Heidi Abrahamse, University of Johannesburg (South Africa)

Tomas Hode, Immunophotonics, Inc. (United States)

Clark E. Tedford, LumiThera (United States)

Session Chairs

1 Present Status and Future Direction With PBM Therapy

Michael R. Hamblin, Wellman Center for Photomedicine (United States)

2 Clinical Translational Research with PBM Therapy

Praveen Arany, University at Buffalo (United States)

3 Clinical Applications of PBM Therapy

James D. Carroll, THOR Photomedicine Ltd. (United Kingdom)

$4 \quad$ PBM Synergistic Therapies

Wei Chen, University of Central Oklahoma (United States) 
Proc. of SPIE Vol. $9695969501-8$

Downloaded From: https://www.spiedigitallibrary.org/conference-proceedings-of-spie on 26 Apr 2023 Terms of Use: https://www.spiedigitallibrary.org/terms-of-use 